УДК 618.14-006.36-089.87

DOI 10.11603/24116-4944.2019.1.10186

\author{
๑М. С. Крохмаль, О. К. Тарасюк, В. В. Трегуб, Ж. М. Бібляк \\ Медичний центр «Людлила» ПМП «Відар», Вінниия
}

\title{
ОРГАНОЗБЕРІГАЛЬНЕ ЛІКУВАННЯ СУБМУКОЗНОЇ МІОМИ МАТКИ МЕТОДОМ ЕМБОЛІЗАЦІї МАТКОВИХ АРТЕРІЙ
}

Мета дослідження - дослідити органозберігальне лікування субмукозної міоми матки шляхом емболізації маткових артерій та запропонувати методику ведення пацієнтів з «народженням» субмукозних вузлів на основі наших спостережень.

Матеріали та методи. Наразі найчастішим методом лікування міоми матки $€$ хірургічний. У репродуктивному віці перевага має віддаватися консервативному лікуванню, а оперативні втручання за можливості повинні мати малоінвазивний і органозберігальний характер. У випадку субмукозної міоми показане хірургічне лікування - гістероскопічна міомектомія, але при розмірах вузла більше 5 см внаслідок високого ризику оперативних ускладнень (кровотечі) методом вибору $є$ емболізація маткових артерій (ЕМА). Даний метод характеризується низьким відсотком післяопераційних ускладнень, практично відсутньою летальністю, збереженням фертильності жінок, швидким відновленням працездатності. Може бути повною альтернативою лікування міоми матки хірургічними методами лікування. Згідно з нашими спостереженнями, відбувається швидке зменшення об'єму міоматозних вузлів і матки протягом першого року після операції до 70 \% від первинного об'єму. У жінки припиняються симптоми - веностискальні (до 95 \% випадків), тиснення на сечовий міхур, геморой, варикоз, попереково-крижові болі, припиняються кровотечі. Відновлюється архітектоніка порожнини матки і трубних кутів.

Результати дослідження та їх обговорення. Міоми субмукозної локалізації - найскладніші у лікуванні даної патології. EMA, на відміну від гістерорезектоскопії, виконується під місцевою анестезією. Субмукозні вузли після ЕМА незалежно від розміру (1 см і більше) і локалізації підлягають регресивним змінам - зменшуються, можуть залишитися у стінці матки або відділяються і відторгаються маткою (залежно від типу) та через статеві шляхи відбувається їх експульсія цілком чи частинами. Міомектомія після ЕMA має вагомі переваги: вузли позбавлені кровотоку, немає загрози кровотечі, відбувається їх зменшення перед експульсією.

Висновки. ЕМА у лікуванні субмукозної міоми є методом вибору як органозберігальна методика. Експульсія вузлів після EMA $€$ наслідком, а не ускладненням. Запропонована нами методика ведення таких жінок дозволяє уникнути гістеректомії і зберегти фрертильність та життя жінки.

Ключові слова: субмукозна міома матки; емболізація маткових артерій; експульсія вузла.

ОРГАНОСОХРАНЯЮЩЕЕ ЛЕЧЕНИЕ СУБМУКОЗНОЙ МИОМЫ МАТКИ МЕТОДОМ ЭМБОЛИЗАЦИИ МАТОЧНЫХ АРТЕРИЙ

Цель исследования - исследовать органосохраняющее лечение субмукозної миомы матки путем эмболизации маточных артерий и предложить методику ведения пациентов с «рождением» субмукозних узлов на основе наших наблюдений.

Материалы и методы. На данный момент наиболее частым методом лечения миомы матки является хирургический. В репродуктивном возрасте предпочтение должно отдаваться консервативному лечению, а оперативные вмешательства по возможности должны носить малоинвазивный и органосохраняющий характер. В случае субмукозной миомы показано хирургическое лечение - гистероскопическая миомэктомия, но при размерах узла более 5 см из-за высокого риска оперативных осложнений (кровотечения) методом выбора является эмболизация маточных артерий (ЭМА). Данный метод характеризуется низким процентом послеоперационных осложнений, практически отсутствием летальности, сохранением фертильности женщин, быстрым восстановлением работоспособности. Может быть полной альтернативой лечения миомы матки хирургическими методами лечения. Согласно нашим наблюдениям, происходит быстрое уменьшение объема миоматозных узлов и матки в течение первого года после операции до 70 \% от первоначального объема. У женщины прекращаются симптомы - веносдавливающие (до 95 \% случаев), давление на мочевой пузырь, геморрой, варикоз, пояснично-крестцовые боли, прекращаются кровотечения. Восстанавливается архитектоника полости матки и трубных углов.

Результаты исследования и их обсуждение. Миомы субмукозной локализации - самые сложные в лечении данной патологии. ЭМА, в отличие от гистерорезектоскопии, выполняется под местной анестезией. Субмукозные узлы после ЭМА независимо от размера (1 см и более) и локализации подлежат регрессивным изменениям - уменьшаются, могут остаться в стенке матки или отделяются и отторгаются маткой (в зависимости от типа) и через половые пути происходит их экспульсия полностью или частями. Миомэктомия после ЭМА имеет весомые преимущества: узлы лишены кровотока, нет угрозы кровотечения, происходит их уменьшение перед экспульсией.

Выводы. ЭМА для лечения субмукозной миомы является методом выбора как органосохраняющая методика. Экспульсия узлов после ЭМА является следствием, а не осложнением. Предложенная нами методика ведения таких женщин позволяет избежать гистерэктомии и сохранить фертильность и жизнь женщины.

Ключевые слова: субмукозная миома матки; эмболизация маточных артерий; экспульсия узла.

ORGAN PRESERVING TREATMENT OF SUBMUCOSOMAL MYOMA BY ARTERY EMBOLIZATION METHOD

The aim of the study - to investigate the organ-preservation treatment of submucosal uterine fibroids by embolization of the uterine arteries and propose a technique for managing patients with "borning" of submucosal nodes based on our observations.

Materials and Methods. Currently, the most common method for treating uterine fibroids is the surgical one. At the reproductive age, the preference should be given to conservative treatment, and surgical interventions should, as far as possible, be carried out in a non-invasive and organ-preserving manner. In case of submucosomal myoma the surgical treatment is used - the hysteroscopic 
myomectomy, but with the size of the node more than $5 \mathrm{~cm}$ due to the high risk of operational complications (bleeding), the choice is the uterine artery embolization (UAE). This method is characterized by a low percentage of postoperative complications, almost absent mortality, preservation of women's fertility, and rapid recovery of disability. It may be a complete alternative to the treatment of uterine fibroids by surgical treatment methods. According to our observations, there is a rapid decrease in the volume of myomatous nodes and uterus during the first year after the operation to $70 \%$ of the original volume. The woman stops feeling the symptoms of vein pressure (up to $95 \%$ of cases), stamina on the bladder, hemorrhoids, varicose, lumbar-sacral pain and bleedings stop. Architectonics of the uterus and tubal angles is restored.

Results and Discussion. Myomas of submucous localization are the most complicated in the treatment of this pathology. UAE unlike the hysteroscopic myomectomy is performed under local anesthesia. Submucosal nodes after UAE, regardless of size (1 cm or more), and localization undergo regressive changes - decrease, may remain in the wall of the uterus or separated and rejected by the uterus (depending on the type) and their expulsion is completely done through the genital tract, or in parts. Myomectomy after UAE has significant advantages: the nodes are deprived of blood flow, there is no threat of bleeding, they decrease before the expulsion.

Conclusions. In the treatment of submucosal fibroids UAE is a method of choice as an organ-preserving method. Expansion of nodes after UAE is a consequence, not a complication. The offered by us method for treating such women avoids hysterectomy and preserves the fertility and life of a woman.

Key words submucosal uterine myoma; uterine artery embolization; node expulsion.

ВСТУП. Міома матки - найпоширеніша пухлина жіночих статевих органів, і є однією з головних причин втрати репродуктивної функції та зниження працездатності жінок фертильного віку. У середньому, в дітородному віці вона зустрічається в кожної 5-ї жінки, а у 50-річному віці може бути виявлена у половини жінок. Слід зазначити, що за останній час почастішали випадки міоми матки у молодих жінок. Це пов'язано не тільки з підвищенням доступності методів діагностики, зокрема УзД, але й «помолодшанням» міоми через зміни в екології та стресогенний спосіб життя сучасного суспільства $[1,2]$.

Міома матки - це захворювання - доброякісний проліферат, виникає через десект 7, 12, 14 хромосом. Десректна м'язова стовбурова клітина є родоначальником моноклонального гормонозалежного утворення - міоми Гормони естрогени відповідають за гіперплазію, прогестерон - за мітотичну активність. Дане утворення у процесі розвитку має псевдокапсулу. У процесі розвитку міоми відбувається бурхливий ангіогенез вузлів, при їх розмірах 5 та більше см виробляється ароматаза, що розчеплює стероїди в естрогеноподібні гормони, що, у свою чергу, посилює гіперпластичні процеси і ріст міоми. Міома у майже 60 \% має рецептори до прогестерону і тому не рекомендується лікування прогестероном. Загалом, вміст естрадіолу і прогестерону в міоматозних вузлах вищий, ніж у нормальному міометрії $[2,3]$.

Найбільший вміст рецепторів естрадіолу і найменший - рецепторів прогестерону у вузлах великих розмірів 3 вираженою пролісрерацією, а при довготриваючих міомах без тенденції до росту - підвищення концентрації прогестеронових рецепторів [1-3].

МЕТА ДОСЛІДЖЕННЯ - дослідити органозберігальне лікування субмукозної міоми матки шляхом емболізації маткових артерій та запропонувати методику ведення пацієнтів з «народженням» субмукозних вузлів на основ наших спостережень.

МАТЕРІАЛИ ТА МЕТОДИ. Наразі найчастішим методом лікування міоми матки є хірургічний, до 80-90 \% випадків - це радикальні операції, які $є$ травматичними для репродуктивної системи жінки. Враховуючи, що матка $€$ органом-мішенню для різних гормональних впливів, то наслідком $€$ посилення нейровегетативних та психоемоційних розладів, збільшення ризику новоутворень травного тракту та інших локалізацій, а також це може спровокувати чи посилити коагулопатичні розлади, оскільки матка - важливе джерело медіаторів, що беруть участь у системі згортання крові в жінок $[5,6]$.

Тому в репродуктивному, і не лише, віці перевага має віддаватися консервативному лікуванню, а оперативні втручання за можливості повинні мати малоінвазивний та органозберігальний характер [6, 7].

У випадку субмукозної локалізації вузла показане хірургічне лікування. Причому зазвичай проводиться гістероскопічна міомектомія, але при розмірах вузла більше 5 см внаслідок високого ризику оперативних ускладнень (кровотечі), навіть після підготовки агоністами гонадотропін-рилізинг-гормонів, тому в такій ситуації методом вибору є емболізація маткових артерій (EMA) [4, 6, 8].

ЕМА широко застосовується з 1995 року для лікування міоми матки, зупинки і профрілактики акушерських кровотеч, патології плаценти, шийкової вагітності, артеріовенозних мальформацій матки, оварикоцеле, аденоміозу, у якості передопераційної підготовки перед міом- та гістеректомією. Даний метод характеризується низьким відсотком післяопераційних ускладнень, практично відсутньою летальністю, збереженням фрертильності жінок, швидким відновленням працездатності. Може бути повною альтернативою лікування міоми матки хірургічними методами лікування [7-9].

Випадок 1. Пацієнтка віком 32 роки. Не народжувала. Шийковий інтрамурально-субсерозний вузол розмірами 9х6 см. Проведена ЕMA і редукція (рис. 1). Через рік відбулося народження вузла. Було складно захопити тканину вузла, внаслідок чого була надірвана капсула вузла. Проведено дренування вузла. Через місяць після масивної антибіотикотерапії даний вузол був видалений у НІІ ПАГ (рис. 2).

Методика EMA основана на тому, що під місцевою анестезією пунктуються стегнові артерії. Далі катетер встановлюється у маткові артерії, і у випадку необхідності - яєчникову артерію. Після цього відбувається повне блокування кровотоку даних судин, що кровопостачають вузол. Під дією кровотоку малого таза емболи, рухаючись по спіральних судинах матки, потрапляють в ендометрій, проходять через нього і покидають матку з настанням менструації. Таким чином, не відбувається нанесення пошкодження міометрію матки. 


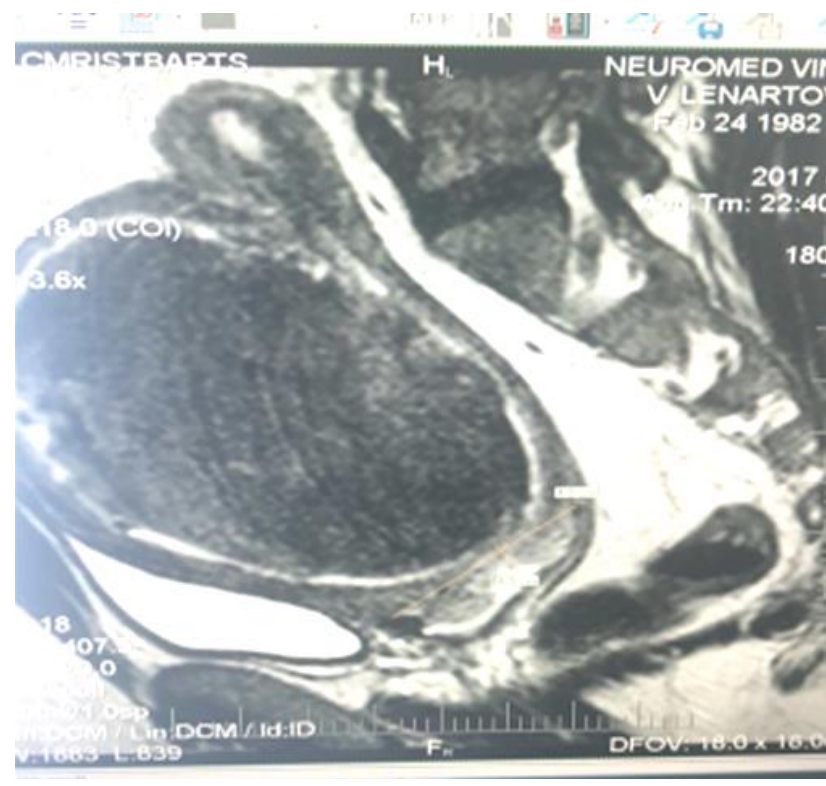

Рис. 1. МРТ. Шийкове розташування вузла, розміром 10 см, при якому була застосована EMA.

Течією крові емболи (ми застосовували bead block compressible microspheres, UK) надходять у судини і через капсулу не можуть вийти з міоми. Наслідками ЕMA $€$ гостра ішемія, фріброз, асептичний червоний некроз і кальцифрікація. Згідно з нашими спостереженнями, відбувається швидке зменшення об'єму міоматозих вузлів і матки протягом першого року після операції до 70 \% від первинного об'єму. У жінки припиняються симптоми - веностискальні (до 95 \% випадків), тиснення на сечовий міхур, геморой, варикоз, попереково-крижові болі, припиняються кровотечі. Відновлюється архітектоніка порожнини матки і трубних кутів. У подальшому міома перетворюється в чужорідне тіло для організму і Т-кілери усе життя лізують тканину міоми (рис. 3,4$)$.

РЕЗУЛЬТАТИ ДОСЛІДЖЕННЯ ТА ЇХ ОБГОВОРЕНня. Міоми субмукозної локалізації - найскладніші у
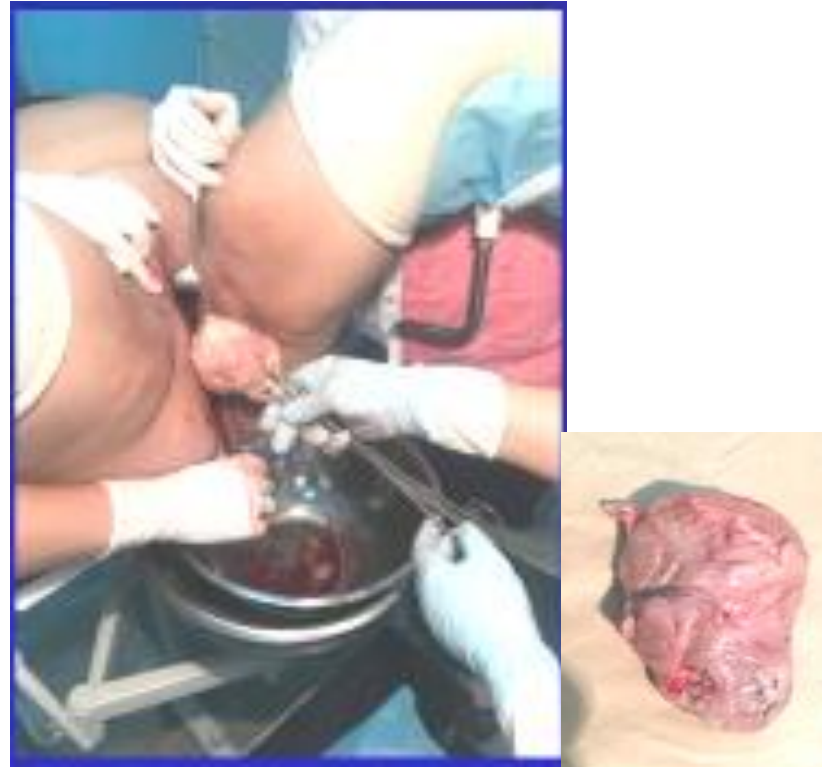

Рис. 2. Міомектомія через 9 міс. після ЕМА.

лікуванні даної патології. Будь-яка гормональна терапія неефективна. Народні засоби не мають наукового обґрунтування. Хірургічна міомектомія - трансвагінальна резектоскопія обмежена розмірами вузлів до $5 \mathrm{~cm}$, загрозою кровотечі, тромбоемболічними ускладненнями (зяють судини після операції, великий відсоток рецидивів протягом 2 років (до $35 \%$ ), можлива перфорація матки, пельвіоперитоніт, що може призвести до гістеректомії і втрати органа. Крім того, гістерорезектоскопія виконується під загальним наркозом, на відміну від ЕМА. Субмукозні вузли після ЕМА незалежно від розміру (1 см і більше) і локалізації підлягають регресивним змінам - зменшуються, можуть залишитися у стінці матки або відділяються і відторгаються маткою (залежно від типу) та через статеві шляхи відбувається їх експульсія цілком чи частинами. Експульсія може настати і через

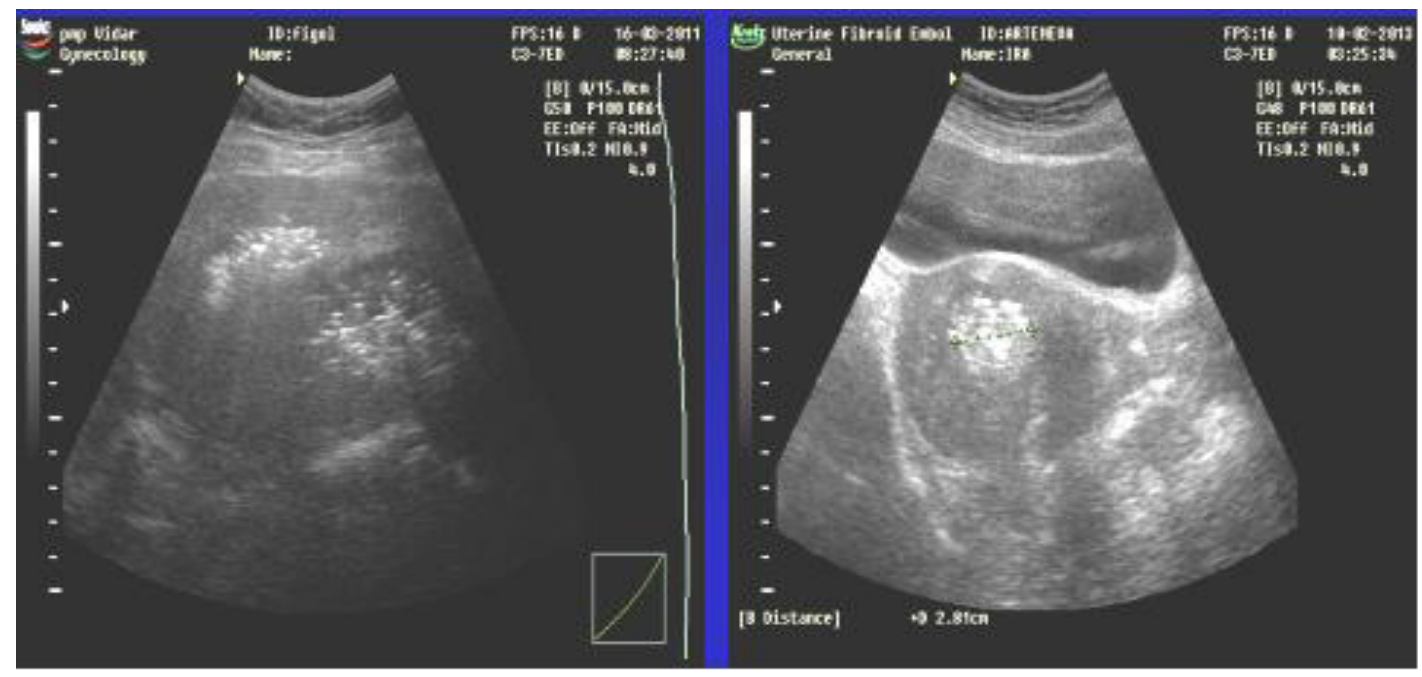

Рис. 3. УЗ-контроль розподілу емболізату в матці одразу після ЕМА. 


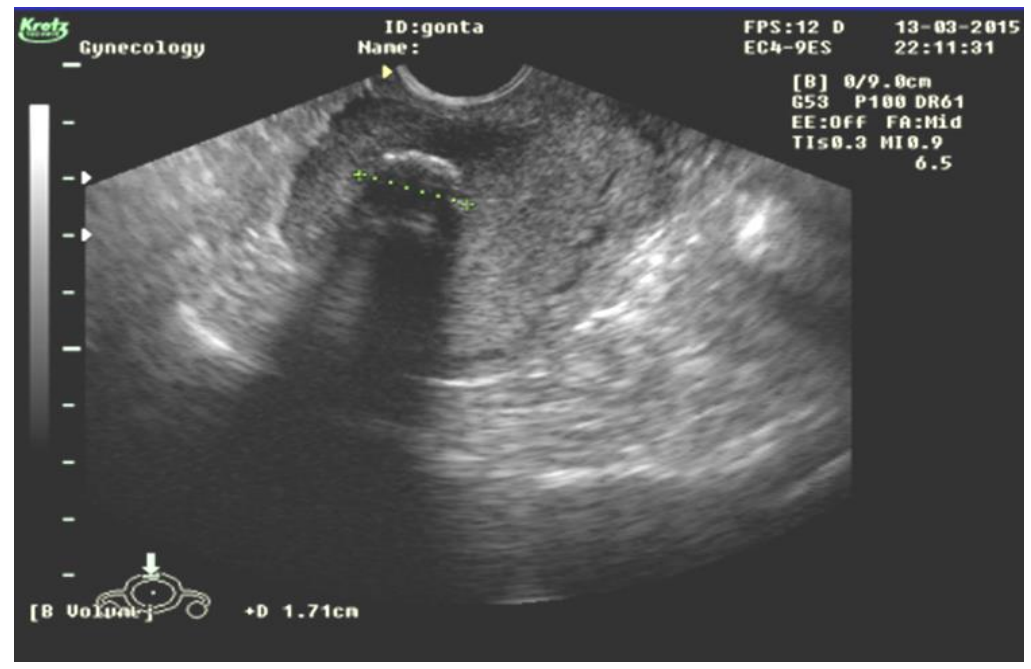

Рис. 4. УзД. Регрес міоматозного вузла через 7 років після ЕМА.

2 тижні, і місяць, і рік (у літературі описано через 44 місяці).

Залежно від типу розташування субмукозних вузлів, описані два варіанти розвитку подій, які умовно поділяються на «мокрий» і «сухий». При «мокрому» сценарії через 10-15 днів після ЕМА міоматозний вузол починає відділятися від стінок матки та «витікати», такий вузол може народитися. У тому випадку, якщо він не може народитися самостійно, необхідно видалити його в умовах малої операційної. При «сухому» варіанті наслідку міоматозний вузол прогресивно зменшується у порожнині матки та експульсується назовні. Експульсія вузла може відбутися під час менструації.

У нашій практиці спостерігали експульсію вузлів від 3 см до 12х6 см. Крупні вузли самостійно вийти через пологові шляхи у 95 \% не можуть, що потребує транвагінальної міомектомії під внутрішньовенним наркозом. Міомектомія після ЕМА має вагомі переваги:

- вузли позбавлені кровотоку, немає загрози кровотечі;

- відбувається їх зменшення перед експульсією внаслідок міолізису;

- вузли можуть видалятися як одним блоком, так і частинами, відділяючись від основної тканини вузла.

Інколи віддаляються частини вузла до 3-5 разів із проміжком до 2 тижнів. Субмукозні вузли можуть складатися з хрящоподібної тканини, покриті м'якою м'язовою тканиною більш пізньої генерації. При затримці вузла у порожнині матки високий ризик інфікування висхідною інорекцією. Тому видалення потребує антибіотикотерапії, У3-діагностики видалення і просування його до внутрішнього вічка. Категорично заборонено видаляти шляхом кюретажу (вишкрібання). При цьому вузол не видалиться цілком, що сприяє проникненню інфекції у маткову порожнину, труби і розвитку розлитого перитоніту.

Ми проводили загальноприйняту техніку видалення такого вузла - після розширення зіва матки розширювачами, використовували щипці Фоерстера (Foerster), які являють собою затискачі прямі та зігнуті, довжиною не менше 25 см. Подальше викручування вузла здійснюється прийомом крокодила - прокручування за чи проти годинникової стрілки. Повторюється доти, доки тканина піддається прокручуванню. При щільній тканині частина вузла не вилучається, а залишається «дозрівати» до наступних місячних. Порожнина не санується через загрозу поширення іноекції через труби у черевну порожнину. Внутрішньовенно застосовуються незначні дози окситоцину для слабкого скорочення матки, що сприяє спусканню вузла до порожнини і захвату вузла. У процесі викручування обережно робити тракцію, забороняється смикати, відщипувати, тому що може призвести до пошкодження стінки матки, перфорації. Міомектомія припиняється, коли вузол не піддається прокручуванню, щільний, добре прикріплений до стінок матки і від нього не відділяються окремі фррагменти. Порожнина матки та зів при цьому «пусті», без тканини. У процесі міомектомії проводиться УЗ-контроль - з оцінкою дугласового простору, стінок матки, порожнини матки. EMA не несе загрози некрозу стінки матки, виникає некроз лише вузла, а не стінки матки.

У медичному центрі за 11 років проведено майже 960 операцій ЕMA при міомі матки і жодного летального випадку не було. Субмукозне розташування вузлів спостерігалося у 17,8 \% серед усіх міом. За цей період проведено 87 операцій трансвагінальної міомектомії субмукозних вузлів після ЕМА (рис. 5, 6).

У жінок з ознаками «народження» субмукозних вузлів клінічні симптоми характеризувалися появою кров'яних виділень, спазматичних болів, інколи підвищенням температури та появою гнійних виділень 3 матки, нерясною кровотечею. У пізніх випадках, якщо вчасно вузол не евакуювати, з'являється неприємний запах, напруження у нижніх відділах живота.

Бімануально визначається згладження шийки матки або відкриття зовнішнього зіва. При УЗ-діагностиці візуалізується частина вузла, що вклинена у внутрішній зів. При розкритті шийки матки вузол може вийти в піхву, скласти хибну уяву експульсії. Насправді частина вузла має дистальну точку прикріплення до стінки матки, тому видалення вузла потребує повного анестезіологічного і гінекологічного забезпечення.

Нами рекомендовано - якщо вузол не відділився від стінки матки, але є симптоми, то призначаються антибіо- 

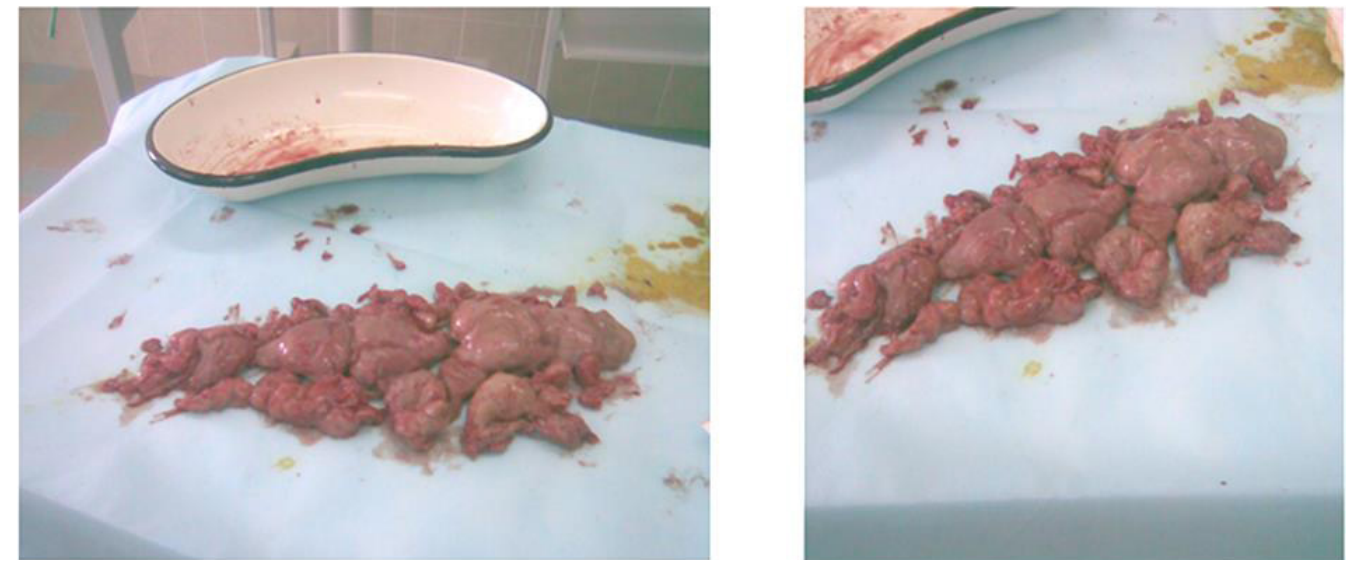

Рис. 5. Видалені шляхом викручування множинні субмукозні вузли.

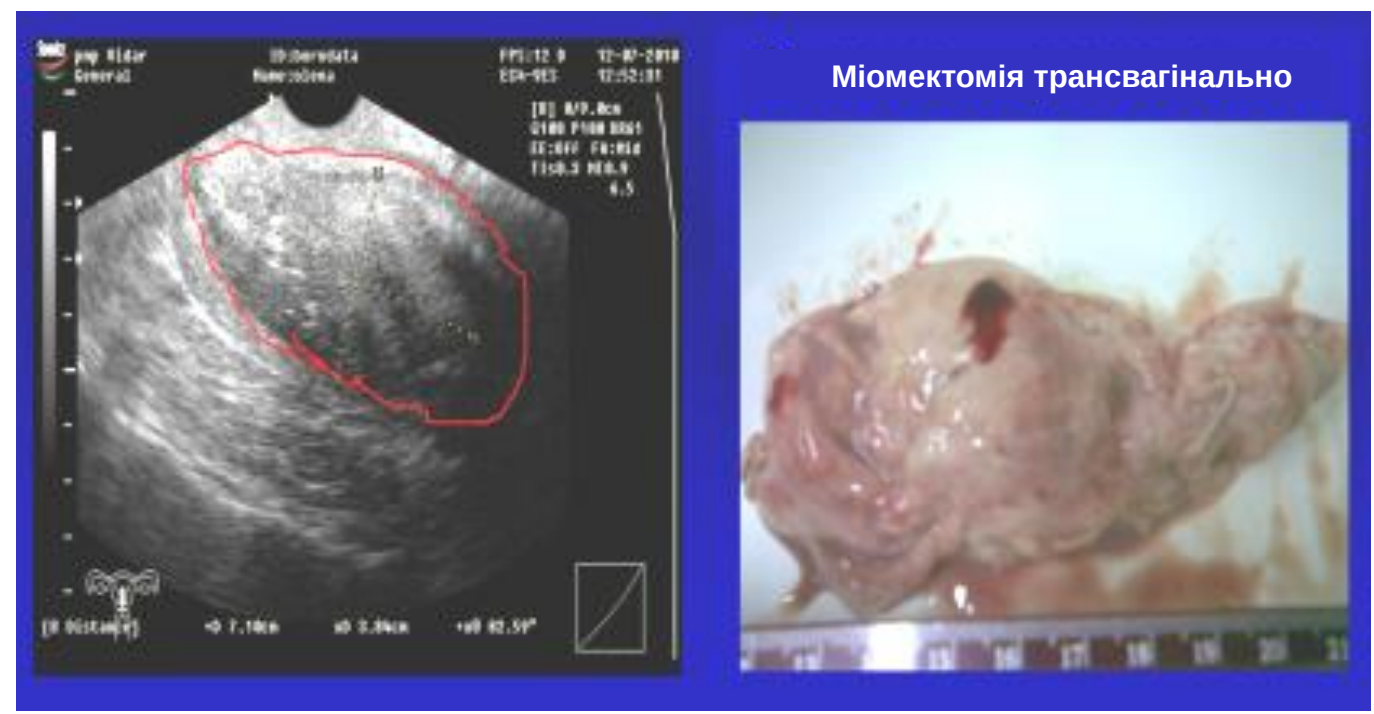

Рис. 6. Видалені субмукозні вузли одним конгломератом та УзД-картина (розмір вузла 6х12 см)

тики широкого спектра дії та проводиться УЗ-контроль у динаміці. Якщо є болі, підвищення температури - проводити ревізію порожнини матки для видалення вузлів та тканин вузла, у порожнині матки (без кюретажу!). При кюретажі - наслідки будуть катастрофічні. Краще дренувати порожнину матки.

Необхідний лабораторний контроль - загальноклінічний аналіз крові з лейкоцитарною фрормулою, рівень фрібриногену.

В динаміці - все приходить до норми при експульсії вузла чи його частин.

Як наслідок, у результаті після трансвагінальної міомектомії жінки є практично здоровими у репродуктивному плані, відновлені трубні кути, розміри матки. При УзДконтролі після даної операції візуалізується рубець у місці прикріплення субмукозного вузла.

Надаються власні клінічні приклади хворих із субмукозними міоматозними вузлами.

Випадок 2. Хвора віком 30 років, матка розмірами 14 тижнів з субмукозним вузлом 6х6 см. Скарги на рясні кровотечі у менструальний та міжменструальний періоди, гемоглобін 62 г/л. Після ЕМА через 2 дні відбулося відділення частини вузла та трансвагінальна міомектомія відділеної тканини. Припинилися міжмісячні кровотечі, гемоглобін збільшився до 120 г/л, зменшилися розміри матки і вузла. Через 2 місяці частина вузла вийшла у піхву. Під анестезіологічним забезпеченням проведено трансвагінальну міомектомію вузла одним блоком. На УЗД після цього виявлено відновлення повністю стінок матки, порожнини і архітектоніки їі. Протягом 3 днів проводили антибіотикотерапію, дезінтоксикаційну терапію і введення фрраксипарину. Лабораторний контроль (рис. 7-10).

За майже 11 років роботи з 87 випадків трансвагінальної міомектомії субмукозних вузлів не було випадків перфорації матки, запалення органів малого таза. Лише в 1 випадку, коли вузол 150 мм через місяць зменшився до 100 мм і став народжуватися, через анатомічні особливості (ожиріння) не було успішним видалення вузла, тому після 2 днів антибіотикотерапії і загрози пельвіоперитоніту через добу після госпіталізації було проведено надпіхвову ампутацію матки без придатків (рис. 11). 

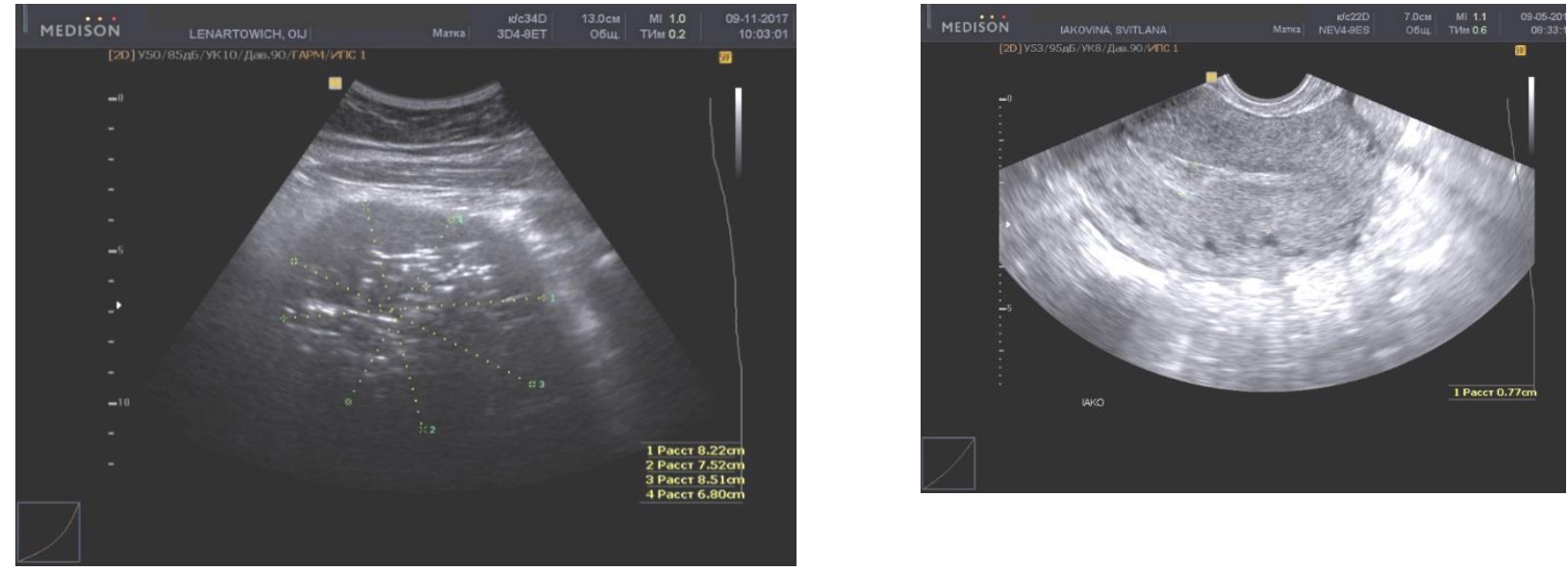

Рис. 7. УЗД-контроль після ЕМА. Емболізат у вузлі.

Рис. 8. УзД при госпіталізації з клінікою експульсії субмукозного вузла.
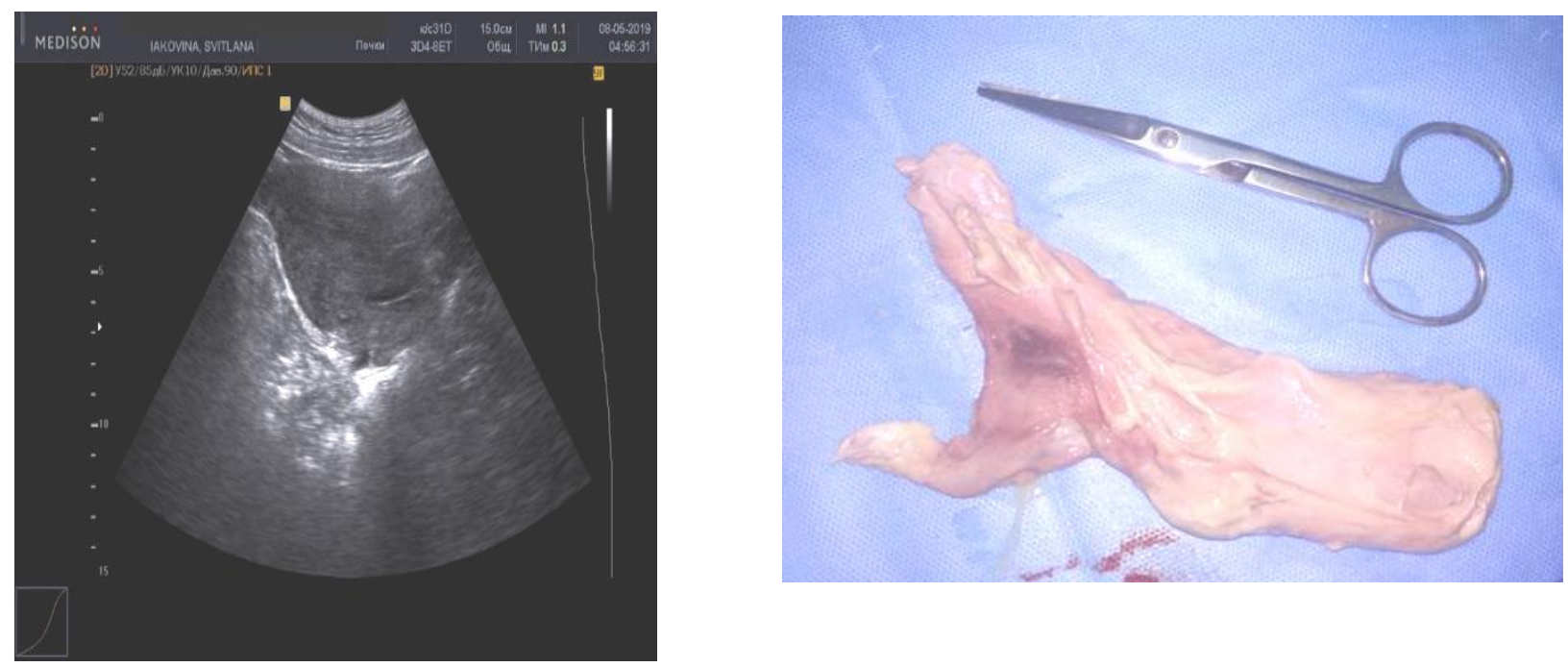

Рис. 9. УзД матки після експульсії вузла.

Рис. 10. Субмукозний вузол після експульсії і видалення.

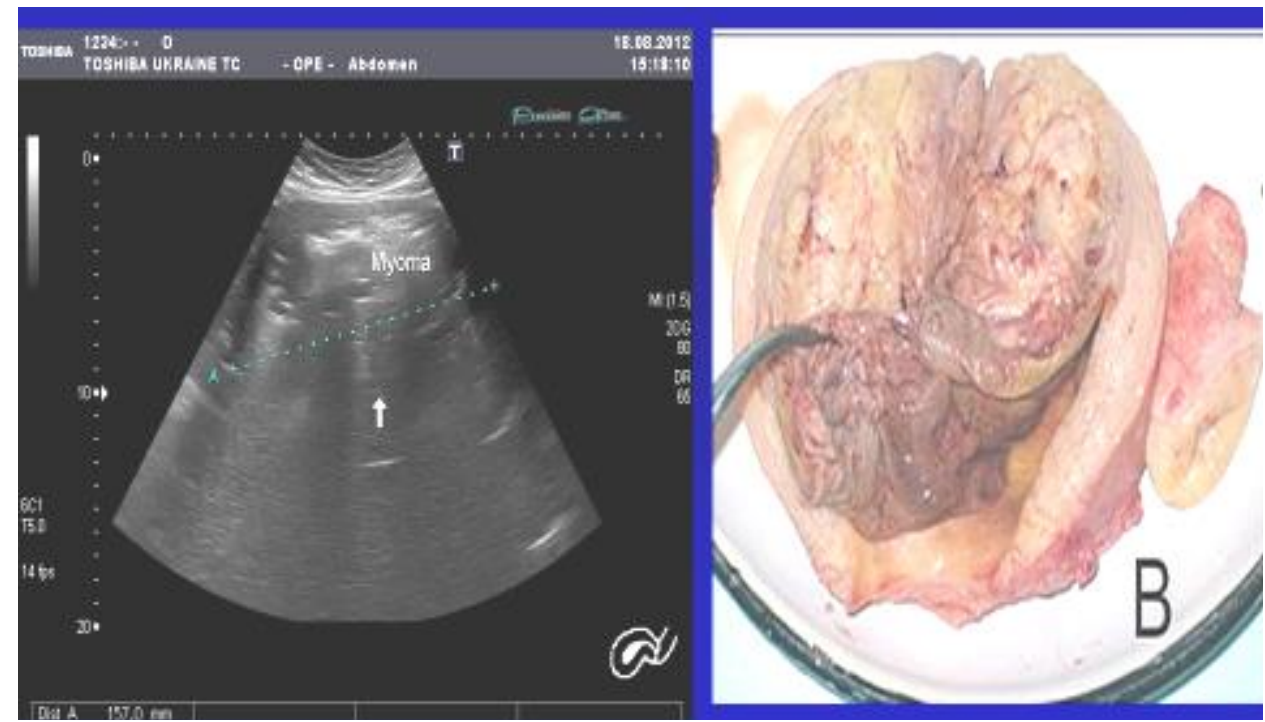

Рис. 11. УзД та макропрепарат після гістеректомії при міомі матки 20 тиж. вагітності. 
ВИСНОВКИ. ЕМА у лікування субмукозної міоми $є$ методом вибору як органозберігальна методика. Експульсія вузлів після ЕМА $є$ наслідком, а не ускладненням, і запропонована нами методика ведення таких жінок дозволяє уникнути гістеректомії і зберегти фрертильність та життя жінки.

\section{СПИСОК ЛІТЕРАТУРИ}

1. Вдовиченко Ю. П. Лейоміома матки: етіопатогенез, профрілактика, діагностика та лікування / Ю.П.Вдовиченко, О. В. Голяновський, І.В.Лопушан // Здоровье женщины. 2012. - № 3. - С. 52-61.

2. Тихомиров А. Л. Миома матки / А. Л. Тихомиров. - М. Медицинское информационное агентство, 2006. - 176 с.

3. Залізняк В. О. Сучасні погляди на лікування міоми матки : навч. посіб. / В. О. Залізняк, Д. Є. Барковський. - Запоріжжя, 2010. - 115 с.

4. Эмболизация маточных артерий: современный взгляд на проблему (часть 2: методические аспекты) / Б. Ю. Бобров С. А. Капранов, В. Г. Бреусенко [и др.] // Диагностическая и интервенционная радиология. - 2007. - Т. 1, № 2. - С. 56-70.

5. Запорожченко М. Б. Лейоміома матки - алгоритми лікування жінок репродуктивного віку / М. Б. Запорожченко // Здоровье женщины. - 2015. - № 5. - С. 55-58.

\section{REFERENCES}

1. Vdovychenko, Yu.P., Holianovskyi, O.V., \& Lopushan, I.V. (2012). Leiomioma matky: etiopatohenez, profilaktyka, diahnostyka ta likuvannia [Leiomyoma of the uterus: etiopathogenesis, prophylaxis, diagnosis and treatment]. Zdorovye zhenshchiny - Health of a Woman, 3, 52-61 [in Ukrainian].

2. Tykhomyrov, A.L. (2006). Mioma matki [Myoma of the uterus]. Moscow: Meditsynskoe informatsyonnoe agenstvo [in Russian].

3. Zalizniak, V.O., \& Barkovskyi, D.Ye. (2010). Suchasni pohliady na likuvannia miomy matky: navch. posib. [Modern views on the treatment of uterine fibroids: teach. manual]. Zaporizhzhia [in Russian].

4. Bobrov, B.Yu., Kapranov, S.A., Breusenko, V.G., \& Dobrokhotova, Yu.E. (2007). Embolizatsiya matochnykh arteriy: sovremennyy vzglyad na problemu (chast 2 : metodicheskiye aspekty) [Uterine artery embolization: a modern view of the problem (part 2: methodological aspects)]. Diagnosticheskaya i interventsionnaya radiologiya - Diagnostic and Interventional Radiology, 1, 2, 56-70 [in Russian].

5. Zaporozhchenko, M.B. (2015). Leiomioma matky alhorytmy likuvannia zhinok reproduktyvnoho viku [Leiomyoma of the uterus - algorithms for the treatment of women of repro-
ПЕРСПЕКТИВИ ПОДАЛЬШИХ ДОСЛІДЖЕНЬ. ЕМболізація маткових артерій $€$ перспективним методом лікування субмукозної міоми матки - як самостійний метод, так і в якості передопераційної підготовки до наступної міомектомії, який зменшує об'єм інтраопераційної крововтрати.

6. Олійник Н. С. Диференційований підхід до використання інноваційних технологій в лікуванні міоми матки : дис. ... канд. мед. наук : 14.01.01 / Н. С. Олійник ; Запорізька медична академія післядипломної освіти. - Запоріжжя, 2016. - 155 с.

7. Профрілактично-терапевтичні заходи при доброякісних пухлинах матки у вагітних / Л. Б. Маркін А. Б. Зіменковський, К. Л. Шатилович, Г. Я. Кунинець // Здоровье женщины. - 2016. - № 2 (108). - С. 75-78.

8. Тихомиров А. Л. Новый принцип лечения миомы матки / А. Л. Тихомиров, А. М. Лубнин. - М., 2007. - 112 с.

9. Сердюк В. М. Результати органозберігального оперативного лікування субмукозної міоми матки при раціональному виборі діагностичних критеріїв / В. М. Сердюк, Ю. О. Чеханов // Медицина транспорту України. - 2012. № 2 (червень). - С. 41.

ductive age]. Zdorovye zhenshchiny - Health of a Woman, 5, 55-58 [in Ukrainian].

6. Oliinyk, N.S. (2016). Dyferentsiiovanyi pidkhid do vykorystannia innovatsiinykh tekhnolohii v likuvannia miomy matky [Differentiated approach to the use of innovative technologies in the treatment of uterine fibroids]. Candidate's thesis. Zaporizhzhia [in Ukrainian].

7. Markin, L.B., Zimenkovskyi, A.B., Shatylovych, K.L. \& Kunynets, H.Ya. (2016). Profilaktychno-terapevtychni zakhody pry dobroiakisnykh pukhlynakh matky u vahitnykh [Prophylactic-therapeutic measures in benign tumors of the uterus in pregnant women]. Zdorovye zhenshchiny - Health of a Woman, 2 (108), 75-78 [in Ukrainian].

8. Tikhomirov, A.L., \& Lubnin, A.M. (2007). Novyy printsip lecheniya miomy matki [The new principle of treatment of uterine fibroids]. Moscow [in Russian].

9. Serdiuk, V.M., \& Chekhanov, Yu.O. (2012). Rezultaty orhanozberihalnoho operatyvnoho likuvannia submukoznoi miomy matky pry ratsionalnomu vybori diahnostychnykh kryteriiv [Results of organ-safe surgical treatment of submucous uterine fibroids with rational choice of diagnostic criteria]. Medytsyna transportu Ukrainy - Transport Medicine of Ukraine, 2, 41 [in Ukrainian]. 